\title{
Enantioselective Conjugate Addition of Aldehydes and Ketones to Maleimides Catalyzed by a Chiral Bifunctional N- benzoimidazol-cyclohexanediamine
}

Talita de A. Fernandes, ${ }^{1,3}$ Diego A. Alonso, ${ }^{2 \star}$ Carmen Nájera $^{2 \star}$ and Paulo R. R. Costa ${ }^{3 *}$ ${ }^{1}$ Instituto de Química, Universidade Federal do Rio de Janeiro, Brasil. ${ }^{2}$ Departamento de Química Orgánica and Instituto de Síntesis Orgánica (ISO), Facultad de Ciencias, Universidad de Alicante, Spain. ${ }^{3}$ Núcleo de

Pesquisas de Produtos Naturais, CCS, Universidade Federal do Rio de Janeiro, Brasil.

*diego.alonso@ua.es; cnajera@ua.es; prrcosta2011@gmail.com

Keywords: Organocatalysis, Maleimides, conjugate addition

\section{INTRODUCTION}

In recent years a wide variety of new chiral organocatalysts have been synthesized and these small molecules efficiently promoted numerous asymmetric transformations, showing the impressive progress exhibited in this area. Despite the remarkable development observed for the organocatalytic enantioselective conjugate addition reactions, ${ }^{2}$ few studies have been reported on the addition to maleimides, an interesting C4-unity. ${ }^{3}$ Functionalized maleimides have been used as intermediate in organic synthesis.

\section{RESULTS AND DISCUSSION}

As a part of our research program aiming the use of aminobenzoimidazols based organocatalyst in conjugate additions, ${ }^{4}$ herein we describe the enantioselective addition of aldehydes and ketones to maleimides. Among the organocatalysts tested, aminobenzoimidazol $\mathbf{1}$, able to activate aldehydes and ketone through imine formation, led to the best preliminary results (Scheme 1).

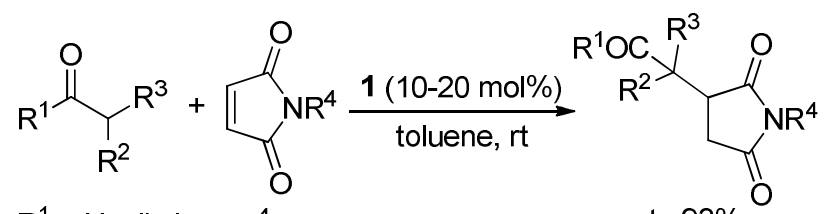
$\mathrm{R}^{1}=\mathrm{H}$, alkyl $\mathrm{R}^{4}=\mathrm{Ph}, \mathrm{Bn}, \mathrm{H}$ up to $93 \%$ ee<smiles>N[C@@H]1CCCC[C@H]1Nc1nc2ccccc2[nH]1</smiles>

Scheme 1. Enantioselective conjugate addition to maleimides

Some products obtained in these reactions, with the yields and ee, are showed in the Figure 1. In particular, conjugate addition of cyclohexanone to $\mathrm{N}$-phenyl and $\mathrm{N}$ - benzyl maleimides led to adducts with very good ee for the main product.

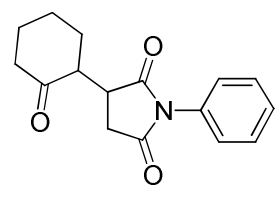

Yield: $53 \%$; dr: $75 / 25$ ee major (1): $93 \%$; ee minor (2): $41 \%$

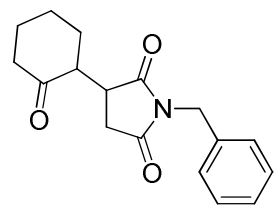

Yield: $55 \%$; dr: 30/70; ee major (2): $93 \%$; ee minor (1): $84 \%$

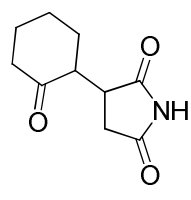

Yield: 45\%; dr: 20/80; ee major (2): $73 \%$; ee minor (1): $40 \%$<smiles>CC(C)(C=O)C1CC(=O)N(c2ccccc2)C1=O</smiles>

Yield: 69\%; ee: 68\%

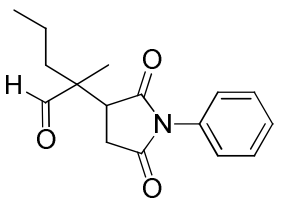

Conv: $95 \%$; dr: $28 / 72$ ee major (2): $75 \%$; ee minor (1): $75 \%$
Figure 1. Products obtained by Michael addition

\section{CONCLUSION}

The catalyst 1 can be used in a satisfactory way for enantioselectives Michael Additions.

\section{ACKNOWLEDGEMENTS}

We thank for the financial support from CAPESDGU (200/09), CNPq, FAPERJ, MEC (PHB20080037-PC), MICINN (CTQ2007-62771/BQU, CTQ2010-20387, Consolider INGENIO 2010 CSD2007-00006), Generalitat Valenciana (GV/2007/142, PROMETEO/2009/038), and the University of Alicante.

\section{REFERENCES}

Enantioselective Organocatalysis, Reactions and Experimental Procedures; Dalko, P. I., Ed.; Wiley-VCH: Weinheim, 2007.

${ }^{2}$ a) Almaşi, D.; Alonso, D. A.; Nájera, C. Tetrahedron: Asymmetry 2007, 18, 299. b) Tsogoeva, S. B. Eur. J. Org. Chem. 2007, 1701. c) Vicario, J. L.; Badía, D.; Carrillo, L. Synthesis 2007, 2065.

${ }^{3}$ Yu, F.; Sun, X.; Jin, Z.; Wen, S.; Liang, X.; Ye, J. Chem. Commun. 2010 4589 , and references cited therein.

${ }^{4}$ Almaşi, D.; Alonso, D. A.; Gómez-Bengoa, E.; Nájera, C. J. Org. Chem. 2009, 74, 6163 . 